\title{
Straight Artery of the Endometrium
}

National Cancer Institute

\section{Source}

National Cancer Institute. Straight Artery of the Endometrium. NCI Thesaurus. Code C33618.

A small artery that originates from the radial artery and supplies the basal layer of the endometrium. 